\title{
Atorvastatin prevents age-related and amyloid- $\beta$-induced microglial activation by blocking interferon- $\gamma$ release from natural killer cells in the brain
}

Anthony Lyons ${ }^{*}$, Kevin J Murphy*, Rachael Clarke and Marina A Lynch

\begin{abstract}
Background: Microglial function is modulated by several factors reflecting the numerous receptors expressed on the cell surface, however endogenous factors which contribute to the age-related increase in microglial activation remain largely unknown. One possible factor which may contribute is interferon- $\gamma$ (IFN $\gamma$ ). IFN $\gamma$ has been shown to increase in the aged brain and potently activates microglia, although its endogenous cell source in the brain remains unidentified.
\end{abstract}

Methods: Male Wistar rats were used to assess the effect of age and amyloid- $\beta$ (A $\beta$ ) on NK cell infiltration into the brain. The effect of the anti-inflammatory compound, atorvastatin was also assessed under these conditions. We measured cytokine and chemokine (IFN $\gamma$, IL-2, monocyte chemoattractant protein-1 (MCP-1) and IFNy-induced protein $10 \mathrm{kDa}(\mathrm{IP-10)})$, expression in the brain by appropriate methods. We also looked at NK cell markers, CD161, NKp30 and NKp46 using flow cytometry and western blot.

Results: Natural killer (NK) cells are a major source of IFN $\gamma$ in the periphery and here we report the presence of $\mathrm{CD}_{161^{+}} \mathrm{NKp} 30^{+}$cells and expression of CD161 and NKp46 in the brain of aged and A $\beta$-treated rats. Furthermore, we demonstrate that isolated $\mathrm{CD} 161^{+}$cells respond to interleukin-2 (IL-2) by releasing IFN $\gamma$. Atorvastatin, the HMGCoA reductase inhibitor, attenuates the increase in CD161 and NKp46 observed in hippocampus of aged and A $\beta$ treated rats. This was paralleled by a decrease in IFN $\gamma$, markers of microglial activation and the chemokines, MCP-1 and IP-10 which are chemotactic for NK cells.

Conclusions: We propose that NK cells contribute to the age-related and A $\beta$-induced neuroinflammatory changes and demonstrate that these changes can be modulated by atorvastatin treatment.

\section{Background}

Microglia express a vast array of receptors [1] indicative of the many factors which can increase their activation. One of the most potent activators of microglia is IFN $\gamma$ and its concentration has been shown to increase in the brain of aged, A $\beta$-treated and LPS-treated animals $[2,3]$. IFN $\gamma$ may act as an endogenous activator of microglial activation but whether it can be released from resident cells in the brain is not clear, although it has been

\footnotetext{
* Correspondence: lyonsan@tcd.ie; murphyk6@tcd.ie

† Contributed equally

Trinity College Institute for Neuroscience, Physiology Department, Trinity College, Dublin 2, Ireland
}

reported that it is produced by microglia of Toxoplasma gondii-infected severe combined immunodeficiency (scid) mice [4].

Natural killer (NK) cells are involved in immune surveillance and responsible for the initial response to viral and pathogenic infection. They express receptors for several cytokines including IL-2 which triggers cell proliferation, cytotoxic activity and release of cytokines, including IFN $\gamma$ [5].

Statins, inhibitors of HMG-CoA reductase, suppress IL-2-induced cytotoxicity of NK cells [6] and attenuate the age-related and $A \beta$-induced microglial activation, and accompanying increase in IFN $\gamma[3,7]$. Here we 
investigated the possibility that IFN $\gamma$ released by infiltrating $\mathrm{CD}_{161^{+}}$cells might contribute to microglial activation in 2 neuroinflammatory models, the aged rat and the $A \beta$-treated rat. We also investigated whether the modulating effect of atorvastatin may be a consequence of its ability to interfere with release of IFN $\gamma$ from these infiltrating cells. The evidence presented here suggests that IFN $\gamma$ plays a role in the age-related and $\mathrm{A} \beta$-induced increase in microglial activation and that the source of the IFN $\gamma$ is $\mathrm{CD} 161^{+}$cells. Importantly, treatment with atorvastatin decreases CD161 and NKp46 (a specific NK cell marker) in the hippocampus of aged and $A \beta$-treated animals and consequently decreases the changes in IFN $\gamma$ and microglial activation.

\section{Methods}

\section{Animals and study design}

Male Wistar rats (Bantham and Kingman, UK; $\mathrm{n}=5-7$ ) aged 3 months (250-350 g) or 22 months (550-650 g), housed in pairs or groups of 4 respectively. All these experiments were performed under license (Department of Health, Ireland) and in accordance with local ethical guidelines.

In the first study, young and aged rats were anaesthetized with urethane $(1.5 \mathrm{~g} / \mathrm{kg}$ intraperitoneally) and transcardially perfused with $200-300 \mathrm{ml}$ saline before tissue was harvested. In the second study, young and aged rats $(n=5-7)$ were divided into a control group and a group that received atorvastatin orally $(5 \mathrm{mg} / \mathrm{kg}$ per day) for 8 weeks. Mean body weights of young animals ( $g$ ) before and after treatment were $222 \pm 9$ and $356 \pm 15$ in the control group and $219 \pm 7$ and $340 \pm 13$ in the atorvastatin-treated group; the corresponding weights in aged rats were $534 \pm 17$ and $555 \pm 22$ (controls) and $527 \pm 16$ and $577 \pm 22$ (atorvastatin). In the third study, young rats, assigned to a control- or an $A \beta$-treated group, were subdivided into rats which did/did not receive atorvastatin ( $5 \mathrm{mg} / \mathrm{kg}$ per day) for 3 weeks; mean body weights $(\mathrm{g})$ before and after treatment were $291 \pm 12$ and $337 \pm 9$ in the control group and $277 \pm$ 13 and $336 \pm 15$ in the atorvastatin-treated group.

Ground atorvastatin calcium tablets (Lipitor ${ }^{\mathrm{TM}}$; PfizerParke Davis, Ireland) were dissolved in vegetable oil ( $5 \mathrm{ml} / 150 \mathrm{~g}$ chow) and added to laboratory chow (Red Mills, Ireland); control animals received laboratory chow with added vegetable oil. The dose of atorvastatin was chosen on the basis of previous findings [3,8]. Food intake (18 g and $25 \mathrm{~g}$ per rats per day for young and aged rats respectively) was assessed before and during the study to ensure animals received their full atorvastatin dose and fresh food was prepared every 2 days. Mean atorvastatin concentrations $( \pm$ SEM; ng ATV/mg protein) in plasma and liver respectively were $0.008 \pm$
0.002 in young rats and $0.005 \pm 0.002$ in aged rats, and $0.026 \pm 0.05$ in young rats and $0.020 \pm 0.05$ in aged rats.

$\mathrm{A} \beta_{1-42}\left(5 \mu \mathrm{l} ; 200 \mu \mathrm{M}\right.$; aggregated for 48 hours at $37^{\circ} \mathrm{C}$; Biosource International Inc. US) or vehicle was delivered intracerebroventricularly $(2.5 \mathrm{~mm}$ posterior and $0.5 \mathrm{~mm}$ lateral to bregma; depth $3.5 \mathrm{~mm}$ ) to urethane-anaesthetized rats [7], on the last day of atorvastatin treatment. [We have previously established that treatment of animals with reverse peptide, $A \beta_{40-1}$ exerted no effect on hippocampal expression of MHCII, CD40 or CD11b mRNA, or on hippocampal IL-1 $\beta$ at mRNA or protein level]. Rats were killed 4 hours after $A \beta$ injection [7], the hippocampus was dissected and used for preparation of dissociated cells by flow cytometry or for analysis of mRNA or for western immunoblot.

\section{Assessment of NK cells by flow cytometry}

Following transcardial perfusion hippocampal tissue was harvested and passed through a cell strainer $(70 \mu \mathrm{m})$ and centrifuged $(170 \times \mathrm{g}, 10 \mathrm{~min})$. The pellet was resuspended in PBS containing collagenase $\mathrm{D}(1 \mathrm{mg} / \mathrm{ml})$ and DNase I $(200 \mu \mathrm{g} / \mathrm{ml})$, incubated at $37^{\circ} \mathrm{C}$ for $30 \mathrm{~min}$ and centrifuged $(170 \times \mathrm{g}, 5 \mathrm{~min})$. Pellets were resuspended in $1.088 \mathrm{~g} / \mathrm{ml}$ Percoll $(9 \mathrm{ml})$, underlaid with $1.122 \mathrm{~g} / \mathrm{ml}$ Percoll $(5 \mathrm{ml})$, and overlaid with $1.072 \mathrm{~g} / \mathrm{ml}$ and 1.030 $\mathrm{g} / \mathrm{ml}(9 \mathrm{ml}$ each) Percoll and PBS $(9 \mathrm{ml})$ and centrifuged $(1250 \times \mathrm{g}, 45 \mathrm{~min})$. The mononuclear cells (between the 1.088:1.072 and 1.072:1.030) were centrifuged and the pellets were washed, and blocked for $15 \mathrm{~min}$ at room temperature in FACS block (Mouse BD Fc Block (BD Pharmingen, UK); 1:500 in FACS buffer). Cells were incubated with CD161a-FITC (1:100 in FACS buffer; BD Biosciences, UK) and NKp30-PE (1:30 in FACS buffer; Santa Cruz Biotechnology Inc, USA). Immunofluorescence analysis was performed on a DAKO Cyan ADP 7 colour flow cytometer (DAKO Cytomation, UK) with Summit v4.3 software.

\section{Isolation of NK cells}

IgG-precoated magnetic beads $\left(100 \mu \mathrm{l} ; 4 \times 10^{6}\right.$ beads; monoclonal human anti-mouse IgG; Invitrogen, UK) were incubated overnight at $4^{\circ} \mathrm{C}$ with mouse anti-rat CD161 primary antibody $(1 \mathrm{mg} / \mathrm{ml}$ : Serotec, UK) or mouse IgG (0.4 mg/ml; Santa Cruz, USA). Perfused hippocampal or cortical tissue was triturated in pre-warmed DMEM (Gibco BRL, Scotland), centrifuged $(2000 \times \mathrm{g}$, $4 \mathrm{~min}$ ) and trypsinized (Tryple Express; Invitrogen, UK; $2 \mathrm{~min}, \mathrm{RT})$. Cells were centrifuged $(2000 \times \mathrm{g}, 4 \mathrm{~min})$, resuspended in DMEM and filtered 3 times, incubated with CD161-coated or IgG-coated beads (2 hours, $4^{\circ} \mathrm{C}$ ) and collected by magnetic isolation. Cell isolation was checked by gel electrophoresis, and visualized following western immunoblot using a monoclonal anti-CD161 
antibody (Serotec, UK) and a HRP-linked secondary antibody. These $\mathrm{CD} 161^{+}$cells were incubated with/without IL-2 (100 ng/ml; Biosource, USA) for 24 hours and IFN $\gamma$ was assessed in supernatants.

In another experiment, a human NK cell line was grown in RPMI with glutamax (Gibco, UK) supplemented with foetal calf serum (10\%; Gibco, UK), penicillin (100 U/ml; Gibco, UK), streptomycin $(100 \mu \mathrm{g} / \mathrm{mg}$; Gibco, UK) and IL-2 (20 ng/ml; R\&D Systems, UK). Cells were washed $(1200 \mathrm{~g} \times 10 \mathrm{~min}) 3$ times, resuspended in warmed media and incubated for 24 hours in the presence/absence of IL-2 $(20 \mathrm{ng} / \mathrm{ml})$. Supernatants were assessed for IFN $\gamma$ by ELISA.

\section{Preparation of mixed glial cultures}

Primary cortical mixed glia were prepared from 1 day old male Wistar rats as previously described [2]. Briefly cortical tissue was chopped, incubated for 5 minutes in $5 \% \mathrm{CO}_{2}$ at $37^{\circ} \mathrm{C}$ in warm filter-sterilized Dulbecco's Modified Eagle Medium (DMEM; Sigma Aldrich, UK) supplemented with penicillin $(100 \mu \mathrm{l} / \mathrm{ml}$; Gibco, UK), streptomycin $(100 \mu \mathrm{l} / \mathrm{ml}$; Gibco, UK) and FBS (10\% w/v; Gibco, UK). A single cell suspension was prepared by triturating tissue, filtering though a $40 \mu \mathrm{m}$ sterile nylon mesh filter (BD Biosciences, USA), centrifuging at $2000 \mathrm{~g}$ for 3 minutes at $20^{\circ} \mathrm{C}$, and resuspending the pellet $1 \mathrm{ml}$ warm filter-sterilized culture media. Tissue was triturated and resuspended glia were counted, equal numbers of cells were plated onto 6 well plates and incubated for 2 hours in $5 \% \mathrm{CO}_{2}$ at $37^{\circ} \mathrm{C}$ to allow the cells to adhere. After 2 hours the cells were flooded with $1 \mathrm{ml}$ warm culture media and incubated for 3 days in $5 \% \mathrm{CO}_{2}$ at $37^{\circ} \mathrm{C}$. Culture media was replaced with fresh culture media every 3 days for 12 days until cells were ready for treatments. After 12 days in culture, cells were incubated in the presence or absence of IFN $\gamma$ ( $50 \mathrm{ng} / \mathrm{ml} ; 24$ hours at $37^{\circ} \mathrm{C}$; R\&D Systems, UK). This concentration has been shown to robustly increase MHCII mRNA [9]. Cells were harvested for analysis of MHCII and CD11b mRNA.

\section{Real-time PCR}

Total RNA was extracted from snap-frozen hippocampal tissue or cultured glial cells using a NucleoSpin ${ }^{\circledR}$ RNAII isolation kit (Macherey-Nagel Inc., Germany). Total RNA concentrations were determined by spectrophotometry, samples were equalised and cDNA synthesis was performed on $1 \mu \mathrm{g}$ total RNA using a High Capacity cDNA RT kit (Applied Biosystems, Germany). Real-time PCR was performed using Taqman Gene Expression Assays (Applied Biosystems, Germany); the assay IDs for MHCII, CD11b, MCP-1 and IP-10 were Rn01768597_m1, Rn00709342_m1, Rn00580555_m1 and Rn00594648_m1, respectively. Real-time PCR was conducted using an ABI Prism 7300 instrument (Applied Biosystems, Germany). A $20 \mu \mathrm{l}$ volume was added to each well $(9 \mu \mathrm{l}$ of diluted cDNA, $1 \mu \mathrm{l}$ of primer and $10 \mu \mathrm{l}$ of Taqman ${ }^{\mathbb{R}}$ Universal PCR Master Mix). Samples were assayed in duplicate $\left(40\right.$ cycles; $95^{\circ} \mathrm{C}$ for $10 \mathrm{~min}, 95^{\circ} \mathrm{C}$ for $15 \mathrm{sec}$ for each cycle (denaturation) and the transcription step at $60^{\circ} \mathrm{C}$ for $1 \mathrm{~min}$ ). $\beta$-actin was the endogenous control (VIC-labeled MGB Taqman probe, Applied Biosystems, Germany; Assay ID: $4352341 \mathrm{E})$. Gene expression was calculated relative to the endogenous control samples and to the control sample giving an RQ value $\left(2^{-\mathrm{DDCt}}\right.$, where $\mathrm{CT}$ is the threshold cycle)

\section{Analysis of CD161 and NKp46 by western blot}

Hippocampal tissue was equalized for protein, aliquots $(10 \mu \mathrm{l})$ were loaded onto $10 \%$ gels, separated $(30 \mathrm{~mA}$; $60 \mathrm{~min})$ and transferred onto nitrocellulose $(225 \mathrm{~mA}$; $90 \mathrm{~min}$ ). Proteins were immunoblotted over night hours at $4^{\circ} \mathrm{C}$ with anti-CD161 antibody (1:500 in TBS containing $0.05 \%$ Tween-20/2\% BSA; Serotec, UK) or antiNKp46 antibody (1:500 in TBS containing 0.05\% Tween-20/2\% BSA; R\&D Systems, UK). Membranes were washed, incubated with the HRP-linked secondary antibody (1:1000; anti-mouse IgG; Sigma, UK) Immunoreactive bands were detected with ECL (GE Healthcare, UK) chemiluminescence. Membranes were then stripped with Re-blot (Re-blot Plus Strong Solution; Chemicon, UK) for $10 \mathrm{~min}$ at room temperature (1:10 dilution; Chemicon International, US) and probed for actin expression (Sigma, UK). Bands were quantified relative to the endogenous control using densitometry (Labworks, UVP BioImaging Systems, UK).

\section{Analysis of IFN $\gamma$ and IL-2}

Cytokines were assessed by ELISA in hippocampal tissue prepared from rats and, in the case of IFN $\gamma$, also in a human NK cell line. For IFN $\gamma$, 96-well plates were coated with monoclonal mouse anti-rat or anti-human antibody. Pre-coated 96-well plates (BioSource, US) were used for analysis of IL-2. Samples or standards, and subsequently detection antibody (biotinylated goat anti-rat or anti-human antibody), were added and after incubation in the presence of streptavidin-horseredish peroxidase, substrate solution was added [2]. Cytokine concentrations were evaluated with reference to standard curves.

\section{Statistical analysis}

Data were analyzed using either Student's t-test for independent means, or a 1 way ANOVA followed by post hoc Student Newman-Keuls test. Data are expressed as means of between 5 and 7 replicates $( \pm$ SEM $)$. 


\section{Results}

Age increases microglial activation and IFN $\gamma$ production in the brain

Here we assessed expression of cell surface markers of microglial activation, and demonstrate age-related increases in MHCII and CD11b mRNA in hippocampal tissue, consolidating earlier findings $[10,11]$. These changes are accompanied by significant increases in IFN $\gamma$ mRNA and protein ( $\mathrm{p}<0.05$ or $\mathrm{p}<0.01$; student's t-test for independent means; Figure 1A-D). IFN $\gamma$ is a potent activator of microglia [12,13] and, consistent with this, we show that incubation of mixed glia in the presence of IFN $\gamma$ significantly increased MHCII and CD11b mRNA ( $p<0.05$ or $\mathrm{p}<0.01$; student's t-test; Figure 1E, F).

\section{Age increases IFN $\gamma$ producing-CD $161^{+} \mathrm{NK}$ cells in the brain}

The resident cell source of IFN $\gamma$ in brain remains unclear. In numerous experiments, we have been unable to stimulate its release with IL-12, IL-2 and IL-18, or LPS from cultured mixed glia or neurons; however, one possible cell source of IFN $\gamma$ is NK cells. The data presented here indicate that there was an age-related increase in the number of $\mathrm{CD} 161^{+} \mathrm{NKp} 30^{+}$cells in the brain ( $p<0.05$; student's t-test; Figure $2 \mathrm{~A}$ ), thus suggesting the specific presence of NK cells. The panel to the right in Figure 2A shows a sample flow cytometry plot, demonstrating increased expression of NKp30 in the aged brain, after gating on the $\mathrm{CD} 161^{+}$cells.

We prepared $\mathrm{CD} 161^{+}$cells from hippocampal and cortical tissue, stimulated them with IL-2 and show that IFN $\gamma$ release was increased between 2 and 3 fold in each case ( $\mathrm{p}<0.05$; student's t-test for independent means; Figures 2B, C) which compares with significant IL-2induced release from a human NK cell line $(\mathrm{p}<0.001$; student's t-test; Figure 2D). However no statistically significant age-related change in IL-2 was observed (Figure 2E).

\section{Atorvastatin attenuates age-related and $A \beta$-induced CD161 expression}

The data indicate that there were age-related increases in expression of CD161 ( $\mathrm{p}<0.05$; ANOVA; Figure 3A) and another marker of NK cells, NKp46 (Figure 3B). This was coupled with increased IFN $\gamma(\mathrm{p}<0.05$; ANOVA; Figure $3 \mathrm{C}$ ) in the aged brain and these changes were attenuated in tissue prepared from aged rats treated with atorvastatin. Similarly the significant age-related increases in CD11b and MHCII, and the chemokines, MCP-1 and IP-10 ( $\mathrm{p}<0.01$ or $\mathrm{p}<0.001$; ANOVA; Figure 3D-G), which are chemotactic for NK cells [14], were also attenuated in hippocampal tissue prepared from atorvastatin-treated aged rats $(\mathrm{p}<0.05$ or $\mathrm{p}<0.01 ;$ ANOVA).

In parallel, we observed that acute inflammation induced by intracerebroventricular injection of $A \beta$, caused a significant increase in expression of CD161 and NKp46 ( $<$ 0.05; ANOVA; Figure 4A, B), This was again correlated with increased IFN $\gamma$ expression in the aged brain ( $\mathrm{p}<0.05$; ANOVA; Figure 4C). These changes were attenuated in tissue prepared from aged rats treated with atorvastatin $(\mathrm{p}<0.05$; ANOVA; Figure $4 \mathrm{~A}-\mathrm{C}) . \mathrm{A} \beta$-induced increases in $\mathrm{CD} 11 \mathrm{~b}$ and $\mathrm{MHCII}$, and the chemokines, MCP-1 and IP-10 ( $\mathrm{p}<0.01$ or $\mathrm{p}<$ 0.001; ANOVA; Figure 4D-G), were also attenuated in rats treated with atrovastatin $(\mathrm{p}<0.05$ or $\mathrm{p}<0.001$; ANOVA).

\section{Discussion}

The significant and novel findings of this study are that CD161-positive cells are observed in the brain under inflammatory conditions, that these cells release IFN $\gamma$. This results in microglial activation, and that treatment of aged or $A \beta$-injected rats with atorvastatin reduces CD161 and NKp46 expression and the consequent increases in IFN $\gamma$ and microglial activation.

Age-related increases in MHCII and CD11b presented here mirror earlier findings [10], as does the parallel increase in IFN $\gamma$ [12]. It is well known that IFN $\gamma$ increases microglial activation and its effect on MHCII and CD11b is similar to that described elsewhere [12], however, key questions remain as to whether resident cells in the brain are capable of producing IFN $\gamma$ and whether endogenous IFN $\gamma$ stimulates microglial activation. It appears that resident brain cells produce IFN $\gamma$ only in very specific circumstances. IFN $\gamma$ transcripts have been identified in human tumour neuroglia and human astroglial cell lines [15] and in microglia prepared from athymic nude and scid mice infected with Toxoplasma gondii [4]. However, we have been unable to detect release of IFN $\gamma$ from cultured glia or neurons following stimulation with LPS or with IL-2, IL-12 or IL-18 alone or in combination with LPS. Therefore, we have considered that NK cells, which are known to be a major source of IFN $\gamma$, might be present in brain and that these cells may be a source of IFN $\gamma$. The data presented here show the presence of NK cell markers, CD161 and NKp46 in the aged hippocampus. The presence of NK cells was then further suggested by flow cytomerty, showing increased numbers of CD161 ${ }^{+} \mathrm{NKp} 30^{+}$cells in the aged hippocampus.

CD161 is one of the archetypal markers of NK cells, and NKp30 and NKp46 are activating receptors present on the surface of NK cells [16]. However, it is acknowledged that CD161 is also on a subset of $\mathrm{CD}^{+}$and $\mathrm{CD}^{+}$ 


\section{A}

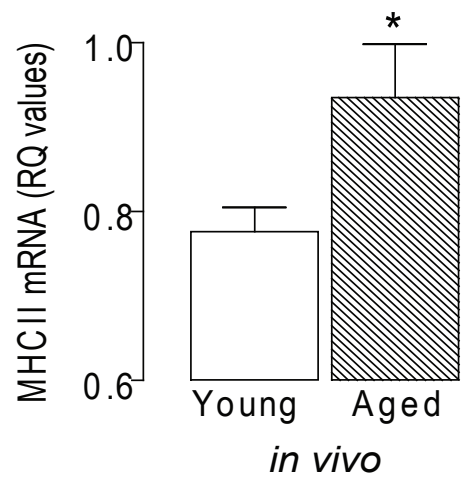

C

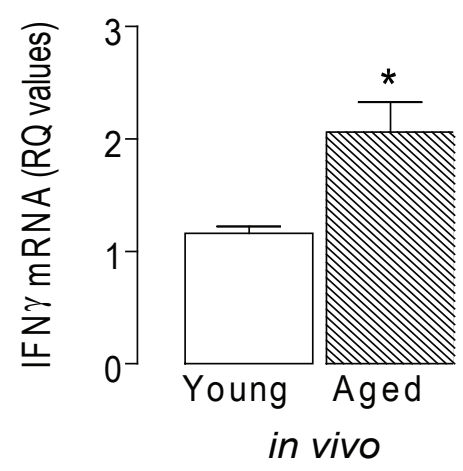

E

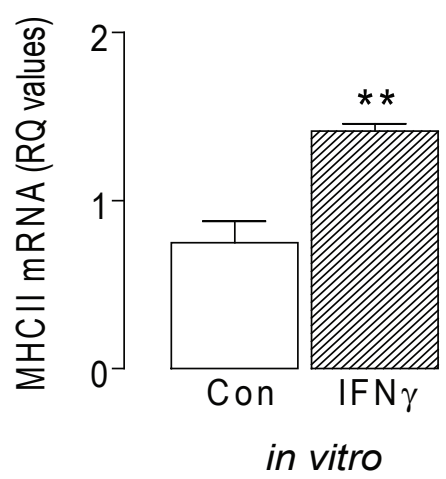

B

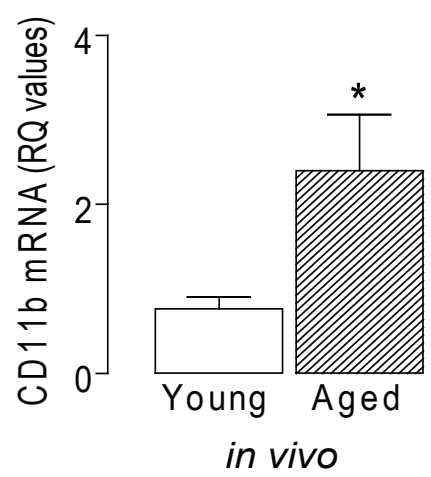

D

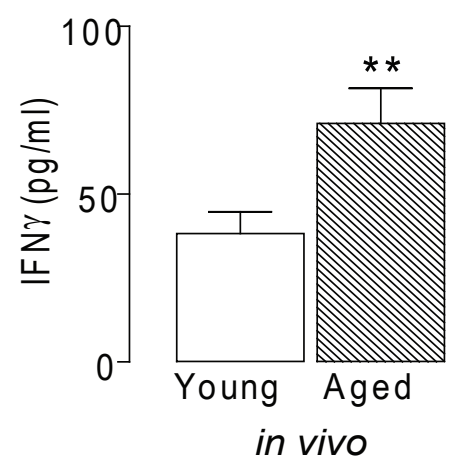

$\mathrm{F}$

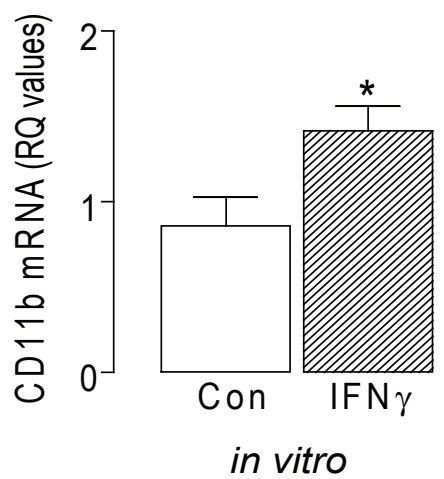

Figure 1 Age related inflammatory changes in the brain. A, MHCII mRNA B, CD11b mRNA C, IFN $\gamma$ mRNA expression, and D, IFN $\gamma$ concentration were significantly increased in hippocampal tissue prepared from aged compared with young rats $\left({ }^{*} p<0.05\right.$; ${ }^{* *} p<0.01$; student's t-test for independent means; $\mathrm{n}=5-7)$. E, IFNy $(50 \mathrm{ng} / \mathrm{ml})$ significantly increased MHCII mRNA and F, CD11b mRNA in cultured glia in vitro. 


\section{A}
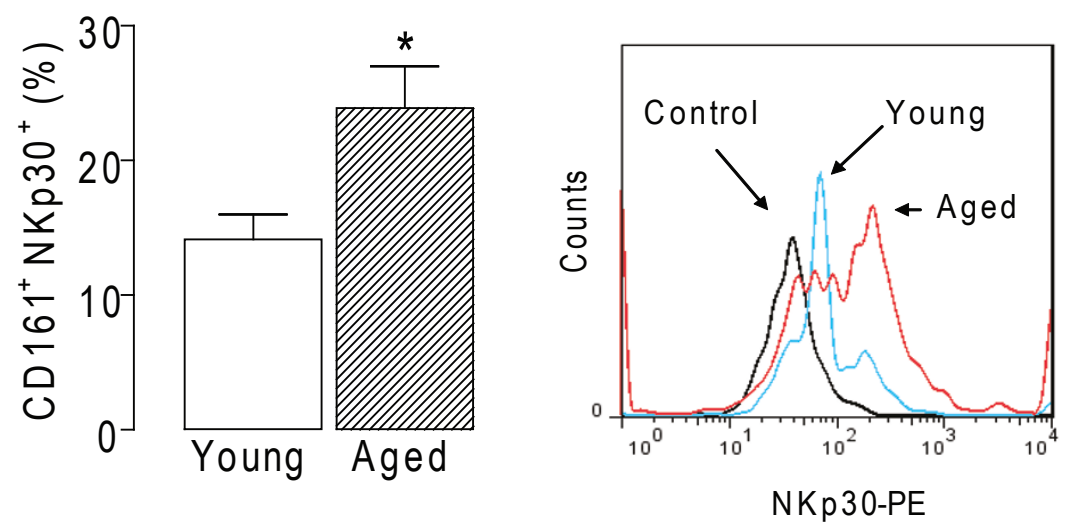

B

C
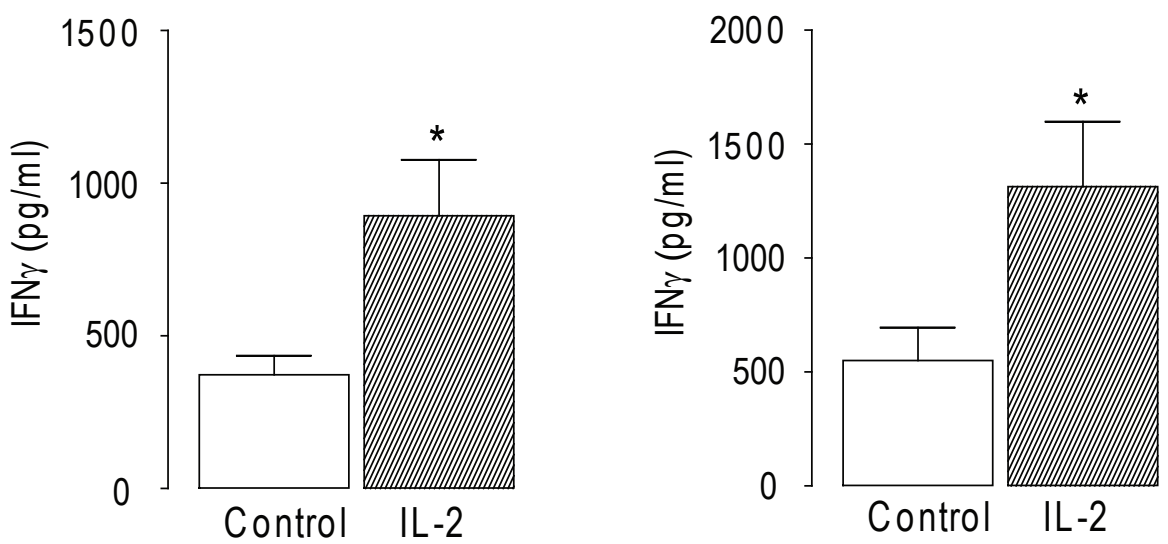

$\mathrm{D}$

E
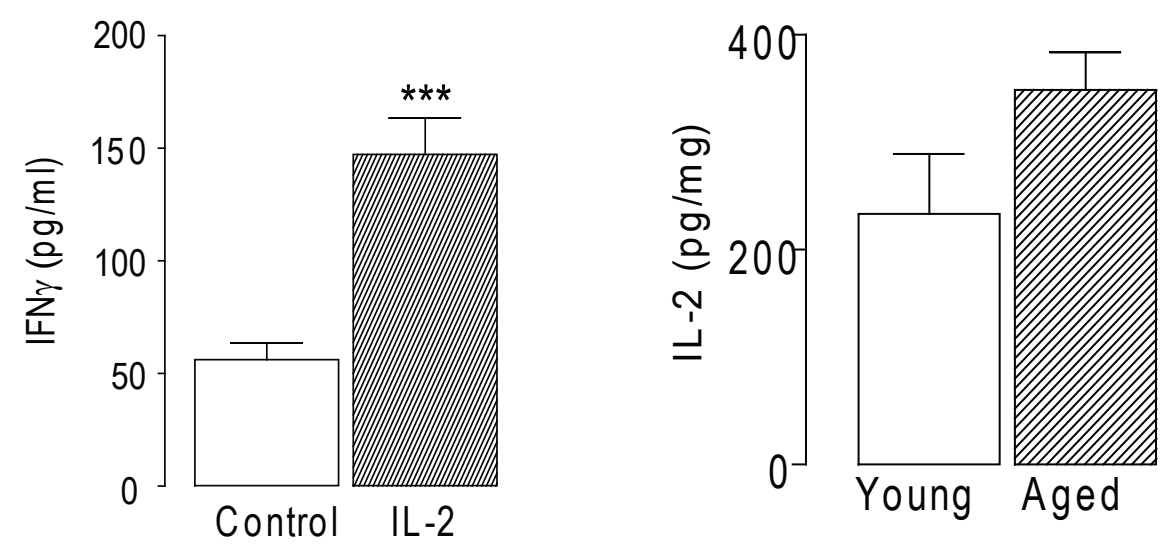

Figure 2 Age-related NK cell infiltration into the brain. $\mathrm{A}, \mathrm{CD}_{161^{+}} \mathrm{NKp} 30^{+}$cells was increased in the hippocampus of aged compared with young rats ( ${ }^{*} p<0.05$; student's t-test for independent means; $n=6$ ). The panel to the right in Figure $2 b$ shows a sample flow cytometry plot, demonstrating increased expression of NKp30 in the aged brain, after gating on the CD161 ${ }^{+}$cells. B, IL-2 increased IFN $\gamma$ release from CD161 cells obtained from rat hippocampus and $\mathrm{C}$, cortex, and $\mathrm{D}$, from a human NK cell line $\left({ }^{*} \mathrm{p}<0.05\right.$; ${ }^{* * *} \mathrm{p}<0.001$; student's t-test for independent means; $n=6$ ). E, IL-2 concentration was not significantly altered in hippocampus of aged and young rats. 
A

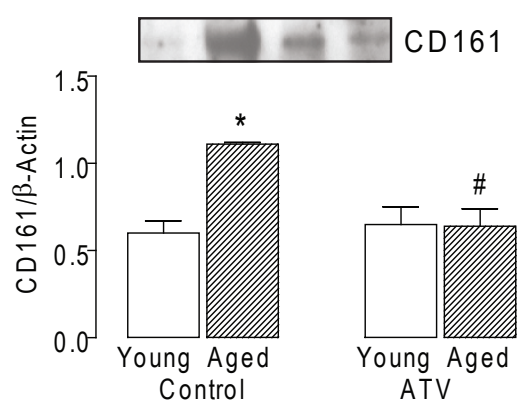

C

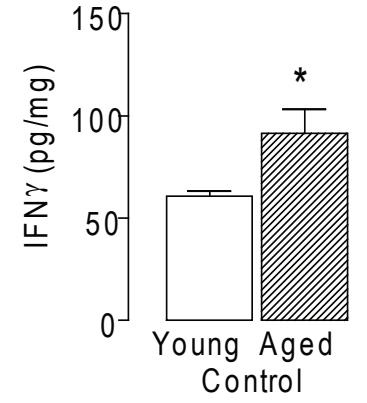

D

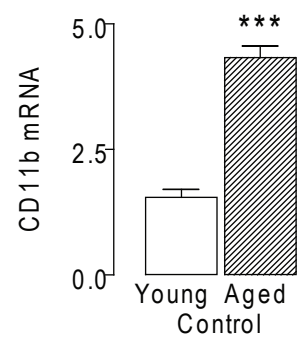

$\mathrm{F}$

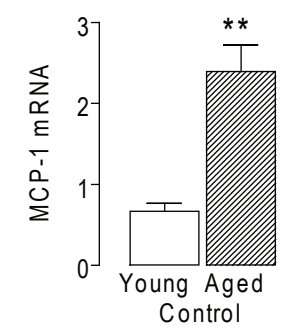

B

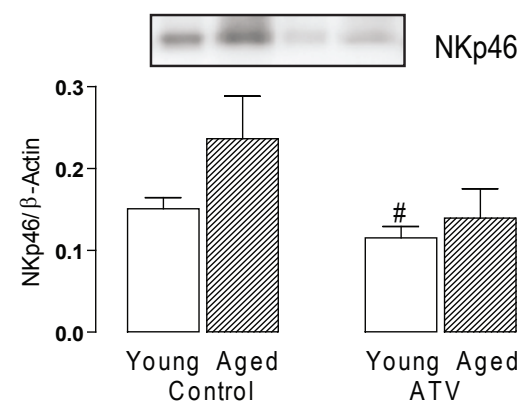

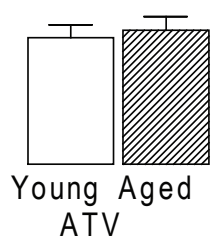

E

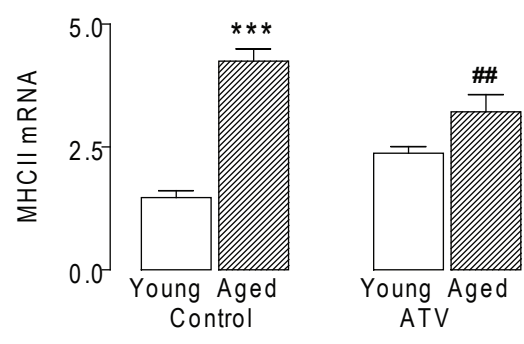

G

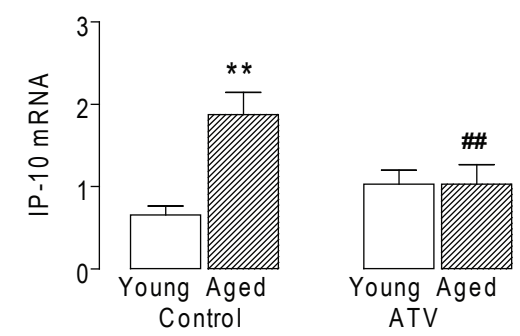

Figure 3 Age-related NK cell induced changes are attenuated by Atorvastatin. A, Expression of CD161 and B, NKp46 assessed by western immunoblotting. Densititometry data is expressed in arbitrary units relative to $\beta$-Actin $C$, IFN $\gamma$ expression, $D, C D 11 b$ mRNA, E, MHCII mRNA, F, MCP-1 mRNA and G, IP-10 mRNA ( ${ }^{*} p<0.05 ;{ }^{* *} p<0.01 ;{ }^{* * *} p<0.001$; ANOVA; $n=6-7$ ) were significantly increased in hippocampal tissue prepared from aged, compared with young rats. These changes were attenuated in hippocampal tissue prepared from aged rats which received atorvastatin (ATV; $5 \mathrm{mg} / \mathrm{kg}$ per day) for 8 weeks (ATV; ${ }^{\#}<0.05 ;{ }^{\# \#} \mathrm{p}<0.01$; vs aged rats which did not receive atorvastatin; ANOVA). 
A

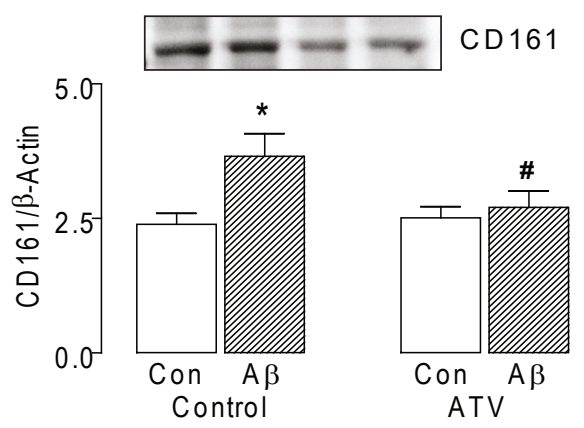

C

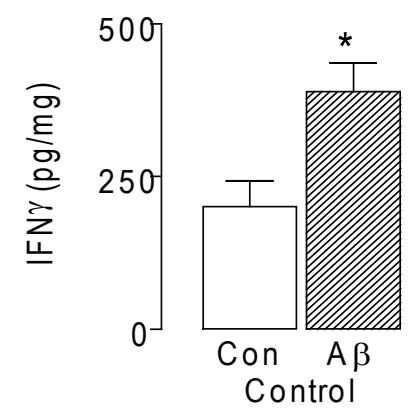

D

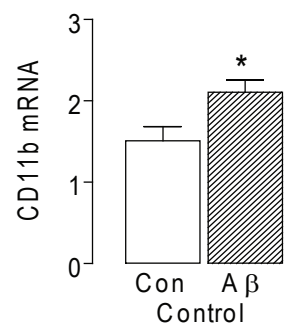

$\mathrm{F}$
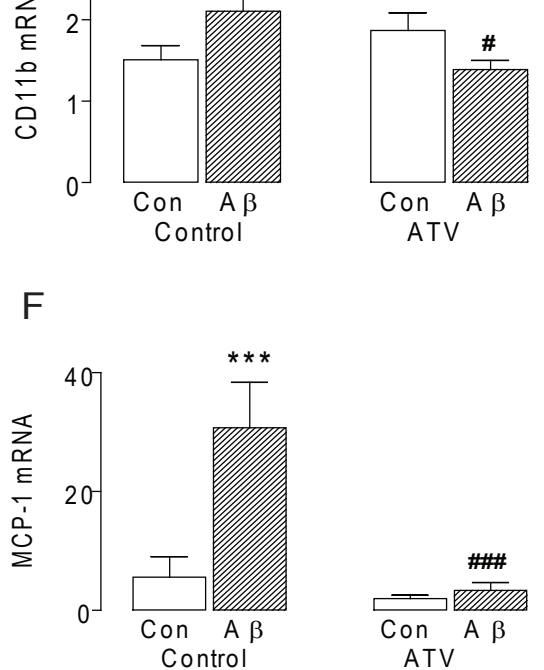

B
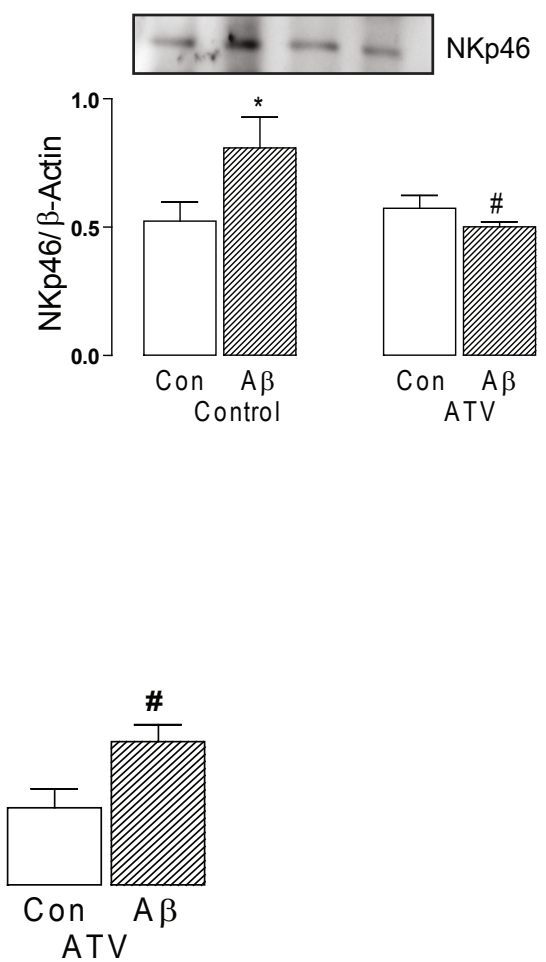

$E$
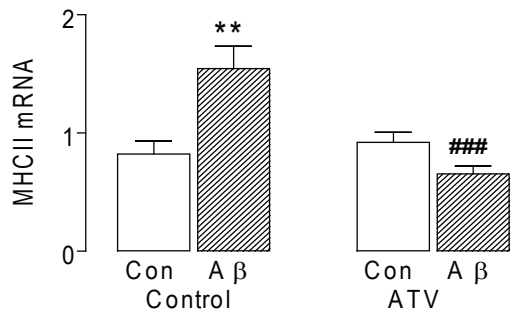

G
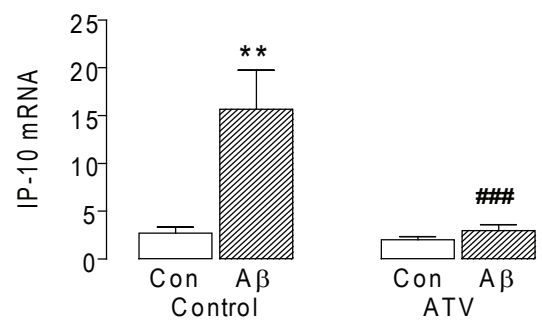

Figure 4 A $\beta$-related NK cell induced changes are attenuated by Atorvastatin. A, Expression of CD161 and B, NKp46 assessed by western immunoblotting. Densititometry data is expressed in arbitrary units relative to $\beta$-Actin $C$, IFNy concentration, $D, C D 11 b$ mRNA, E, MHCII mRNA, F, MCP-1 mRNA and G, IP-10 mRNA ( ${ }^{*} p<0.05 ;{ }^{* *} p<0.01 ;{ }^{* * *} p<0.001$; ANOVA; $n=6-7$ ) were significantly increased in hippocampal tissue prepared from rats which received an intracerebroventricular injection of $A \beta_{1-42}(5 \mu \mathrm{l} ; 200 \mu \mathrm{M})$ or vehicle. These changes were attenuated in hippocampal tissue prepared A $\beta$-treated rats which received atorvastatin (ATV; $5 \mathrm{mg} / \mathrm{kg}$ per day) for 3 weeks (ATV; $\#<0.05 ; \#$; $p<0.001 ;$ vs A treated rats which did not receive atorvastatin; ANOVA). 
$\mathrm{T}$ cells [17] but previous work has shown that $\mathrm{T}$ cells are only present in very low numbers in brain [18]. These data presented here suggest that infiltration of cells occurs more readily in the brain of aged and $A \beta$-treated rats compared with young rats. This may be a consequence of the reported inflammatory-mediated increase in blood brain barrier (BBB) permeability [19], an increased change in molecules chemotactic for NK cells or both. Interestingly the age-related and $\mathrm{A} \beta$-induced increase in CD161 and NKp46 is paralleled by increased hippocampal expression of IP-10 and MCP-1, both of which have been shown to promote chemotaxis of NK cells $[14,20]$.

IL-2, IL-12 and IL-18 all potently stimulate release of IFN $\gamma$ from NK cells [21] and here we show that IL-2 increases IFN $\gamma$ release from $\mathrm{CD} 161^{+}$cells prepared from cortex and hippocampus. However, IL-2 expression in hippocampus was not altered significantly with age suggesting that the increase in IFN $\gamma$ results from the increased infiltration of NK cells into the brain rather than any change caused by IL- 2 .

Atorvastatin decreased CD161 and NKp46 expression in the brain of aged rats, suggesting that NK cell numbers in the brain may be decreased. Interestingly atorvastatin has been shown to increase patency of the BBB in a hypertension model, by increasing expression of two tight junction proteins, zonula occludens- 1 and occludin [22]. The present findings, which indicate that atorvastatin decreased the age-related expression of MCP-1 and IP-10, suggest that the atorvastatin-induced loss of the chemotactic signal may also contribute to the reduction in CD161 and NKp46. Consistent with our proposal that IFN $\gamma$, derived from NK cells, contributes to microglial activation in the brain of aged rats, we show that the atorvastatin-associated change in CD161 and NKp46 was accompanied by an attenuation of the age-related changes in MHCII, CD11b and IFN $\gamma$; these changes precisely mirror our earlier observations [3]. It is interesting to note that atorvastatin treatment alone caused a slight increase in expression of CD161, CD11b, MHCII, and IP10 , although this increase did not reach statistical significance; these effects are apparently independent of IFN $\gamma$ and NKp46. One possibility may be that atorvastatin decreased coenzyme Q10 expression which is known to increase inflammation [23]. The fact that these chages were evidence only when rats were treated with atorvastatin for 8 weeks, rather than 3 weeks, reflects the finding that changes in coenzyme Q10 appear to be dependent on the type of statin used and the duration of the treatment \{Marcoff, 2007 \#1940\}.

The age-related increase in CD161 and NKp46 was replicated by intracerebroventricular injection of $A \beta$, suggesting that NK cells also infiltrate the brain in this model. BBB permeability has been shown to be compromised in a mouse model of Alzheimer's disease [24], while soluble $A \beta$ has been shown to stimulate inflammatory changes in the vasculature [25] and to permit monocyte infiltration into the brain [26]. The A $\beta$-induced increase in CD161 and NKp46 was paralleled by microglial activation and chemokine production, mirroring the age-related changes. Atorvastatin attenuated the $A \beta$-induced changes as it did the age-related changes, and this replicates some of our earlier findings [7]. The modulatory effects of atorvastatin on microglial activation may provide some insight into why epidemiological evidence suggests that statins reduce the incidence of $\mathrm{AD}$; one possibility is that its primary effect is on correcting any compromise in BBB permeability [22] and consequently prevents infiltration of NK cells, that lead to subsequent microglial activation and inflammatory changes.

\section{Conclusion}

The findings described here provide the first evidence that cells which have a number of phenotypic characteristics of NK cells are present in the aged brain, and the data suggest that these cells may release IFN $\gamma$ which acts to stimulate microglial activation. This microglial activation can be reversed by treatment with atorvastatin which works by down-regulating the expression of IP-10 and MCP-1, chemoattractant molecules for NK cells.

\section{Acknowledgements}

This work was supported by Science Foundation Ireland, The Health Research Board and The Higher Education Authority, Ireland (PTRLI)

\section{Authors' contributions}

$\mathrm{AL}$ and KJM contributed to design of the study, performed the cell isolation western blot, Real-Time PCR and FACS analysis, and reviewed and organized the data; RC performed all atrovastatin related animal treatments, tissue preparation, IFNY ELISAs and reviewed the manuscript; MAL directed the overall study, analysis of the data, wrote and reviewed the manuscript. All authors have read and approved the final manuscript.

\section{Competing interests}

The authors declare that they have no competing interests.

Received: 12 January 2011 Accepted: 31 March 2011

Published: 31 March 2011

\section{References}

1. Lucin KM, Wyss-Coray T: Immune activation in brain aging and neurodegeneration: too much or too little? Neuron 2009, 64:110-122.

2. Lyons A, Griffin RJ, Costelloe CE, Clarke RM, Lynch MA: IL-4 attenuates the neuroinflammation induced by amyloid-beta in vivo and in vitro. $J$ Neurochem 2007, 101:771-781.

3. Clarke RM, Lyons A, O'Connell F, Deighan BF, Barry CE, Anyakoha NG, Nicolaou A, Lynch MA: A pivotal role for interleukin-4 in atorvastatinassociated neuroprotection in rat brain. J Biol Chem 2008, 283:1808-1817.

4. Suzuki Y, Claflin J, Wang X, Lengi A, Kikuchi T: Microglia and macrophages as innate producers of interferon-gamma in the brain following infection with Toxoplasma gondii. Int J Parasitol 2005, 35:83-90.

5. Borrego F, Robertson MJ, Ritz J, Pena J, Solana R: CD69 is a stimulatory receptor for natural killer cell and its cytotoxic effect is blocked by CD94 inhibitory receptor. Immunology 1999, 97:159-165. 
6. Tanaka T, Porter CM, Horvath-Arcidiacono JA, Bloom ET: Lipophilic statins suppress cytotoxicity by freshly isolated natural killer cells through modulation of granule exocytosis. Int Immunol 2007, 19:163-173.

7. Clarke RM, O'Connell F, Lyons A, Lynch MA: The HMG-CoA reductase inhibitor, atorvastatin, attenuates the effects of acute administration of amyloid-beta1-42 in the rat hippocampus in vivo. Neuropharmacology 2007, 52:136-145.

8. Youssef S, Stuve O, Patarroyo JC, Ruiz PJ, Radosevich JL, Hur EM, Bravo M, Mitchell DJ, Sobel RA, Steinman L, Zamvil SS: The HMG-CoA reductase inhibitor, atorvastatin, promotes a Th2 bias and reverses paralysis in central nervous system autoimmune disease. Nature 2002, 420:78-84.

9. Maher FO, Clarke RM, Kelly A, Nally RE, Lynch MA: Interaction between interferon gamma and insulin-like growth factor-1 in hippocampus impacts on the ability of rats to sustain long-term potentiation. $J$ Neurochem 2006, 96:1560-1571.

10. Cowley TR, O'Sullivan J, Blau C, Deighan BF, Jones R, Kerskens C, Richardson JC, Virley D, Upton N, Lynch MA: Rosiglitazone attenuates the age-related changes in astrocytosis and the deficit in LTP. Neurobiol Aging .

11. Downer EJ, Cowley TR, Lyons A, Mills KH, Berezin V, Bock E, Lynch MA: A novel anti-inflammatory role of NCAM-derived mimetic peptide, FGL. Neurobiol Aging 31:118-128.

12. Downer EJ, Cowley TR, Cox F, Maher FO, Berezin V, Bock E, Lynch MA: A synthetic NCAM-derived mimetic peptide, FGL, exerts anti-inflammatory properties via IGF-1 and interferon-gamma modulation. J Neurochem 2009, 109:1516-1525.

13. Benveniste EN, Nguyen VT, Wesemann DR: Molecular regulation of CD40 gene expression in macrophages and microglia. Brain Behav Immun 2004, 18:7-12.

14. Muller M, Carter S, Hofer MJ, Campbell IL: Review: The chemokine receptor CXCR3 and its ligands CXCL9, CXCL10 and CXCL11 in neuroimmunity-a tale of conflict and conundrum. Neuropathol Appl Neurobiol 36:368-387.

15. Nitta T, Ebato M, Sato K, Okumura K: Expression of tumour necrosis factoralpha, -beta and interferon-gamma genes within human neuroglial tumour cells and brain specimens. Cytokine 1994, 6:171-180.

16. Pende D, Parolini S, Pessino A, Sivori S, Augugliaro R, Morelli L, Marcenaro E, Accame L, Malaspina A, Biassoni R, et al: Identification and molecular characterization of NKp30, a novel triggering receptor involved in natural cytotoxicity mediated by human natural killer cells. J Exp Med 1999, 190:1505-1516.

17. Lanier LL, Chang C, Phillips JH: Human NKR-P1A. A disulfide-linked homodimer of the C-type lectin superfamily expressed by a subset of NK and T lymphocytes. J Immunol 1994, 153:2417-2428.

18. Babcock AA, Toft-Hansen H, Owens T: Signaling through MyD88 regulates leukocyte recruitment after brain injury. J Immunol 2008, 181:6481-6490.

19. Bake S, Friedman JA, Sohrabji F: Reproductive age-related changes in the blood brain barrier: expression of $\lg G$ and tight junction proteins. Microvasc Res 2009, 78:413-424.

20. Inngjerdingen M, Damaj B, Maghazachi AA: Expression and regulation of chemokine receptors in human natural killer cells. Blood 2001, 97:367-375.

21. Pintaric M, Gerner W, Saalmuller A: Synergistic effects of IL-2, IL-12 and IL18 on cytolytic activity, perforin expression and IFN-gamma production of porcine natural killer cells. Vet Immunol Immunopathol 2008, 121:68-82.

22. Kalayci R, Kaya M, Elmas I, Arican N, Ahishali B, Uzun H, Bilgic B, Kucuk M, Kudat $\mathrm{H}$ : Effects of atorvastatin on blood-brain barrier permeability during L-NAME hypertension followed by angiotensin-II in rats. Brain Res 2005, 1042:184-193.

23. Marcoff L, Thompson PD: The role of coenzyme Q10 in statin-associated myopathy: a systematic review. J Am Coll Cardiol 2007, 49:2231-2237.
24. Dickstein DL, Biron KE, Ujiie M, Pfeifer CG, Jeffries AR, Jefferies WA: Abeta peptide immunization restores blood-brain barrier integrity in Alzheimer disease. FASEB J 2006, 20:426-433.

25. Paris D, Town T, Mori T, Parker TA, Humphrey J, Mullan M: Soluble betaamyloid peptides mediate vasoactivity via activation of a proinflammatory pathway. Neurobiol Aging 2000, 21:183-197.

26. Giri R, Shen Y, Stins M, Du Yan S, Schmidt AM, Stern D, Kim KS, Zlokovic B, Kalra VK: beta-amyloid-induced migration of monocytes across human brain endothelial cells involves RAGE and PECAM-1. Am J Physiol Cell Physiol 2000, 279:C1772-1781.

doi:10.1186/1742-2094-8-27

Cite this article as: Lyons et al:: Atorvastatin prevents age-related and amyloid- $\beta$-induced microglial activation by blocking interferon- $\gamma$ release from natural killer cells in the brain. Journal of Neuroinflammation 2011 8:27.

\section{Submit your next manuscript to BioMed Central and take full advantage of:}

- Convenient online submission

- Thorough peer review

- No space constraints or color figure charges

- Immediate publication on acceptance

- Inclusion in PubMed, CAS, Scopus and Google Scholar

- Research which is freely available for redistribution

Submit your manuscript at www.biomedcentral.com/submit
C) Biomed Central 